\title{
PEMBIAYAAN QARDH AL-HASAN DALAM MENINGKATKANPRODUKTIVITAS USAHA KECIL NASABAH
}

\author{
Dewi Fatmasari, S.E.M.Si. \\ dewifatmasari73@gmail.com \\ Fakultas Syariah dan Ekonomi Islam IAIN Syekh Nurjati Cirebon \\ Dini Widyaningsih \\ Fakultas Syariah dan Ekonomi Islam IAIN Syekh Nurjati Cirebon
}

\begin{abstract}
ABSTRAK
BMT merupakan salah satu lembaga keuangan syariah yang secara konseptual memberikan dampak yang begitu besar bagi para pengusaha kecil. Lembaga keuangan ini secara signifikan memberdayakan masyarakat kelas paling bawah. Pembiayaan qardh al-hasanmerupakan salah satu pembiayaan yang ada di BMT dengan prinsip pinjaman sosial,yangmerupakan pinjaman murni tanpa adanya biaya tambahan. Oleh karena itu dengan adanya pembiayaan qardh al-hasan diharapkanakan mampu membantu para usaha kecil dalam meningkatkan produktivitas usahanya.

Kata Kunci :Pembiayaan Qardh al-Hasan, Produktivitas Usaha Keci l
\end{abstract}

\section{PENDAHULUAN}

Indonesia merupakan negara berkembang dengan jumlah pengusaha kecilmencapai $\pm 39,04$ juta jiwa. Namun pengusahakecil tersebut tidak memilikiakses ke lembaga perbankan sebagai lembaga permodalan. Bagi usaha kecil dengan omset kurang dari Rp 50 juta perbulan atau lebih dikenal dengan usaha mikro, umumnya tantangan yangdihadapi adalah bagaimana menjaga kelangsungan hidupusahanya. Mereka pada umumnya tidak membutuhkan modal yang besar untuk ekspansi produksi,biasanya modal yang diperlukan sekedar membantu kelancarancash flow. ${ }^{1}$

\footnotetext{
${ }^{1}$ Farida, Nurul, Analisis Pembiayaan Al Bai u Bitsaman Ajil Bagi Usaha
}

Semakinmeningkatnya

perkembangan usaha kecil dan menengah, menyebabkan semakin meningkatnya taraf kemakmuranp erek on omian masyarakat. Namun,perkembangan usaha kecil dan menengah tersebut tidakdisertai dengan tingkatmodal yang mencukupi, sehingga untuk menambah modal tersebut banyakperusahaan atau pelaku bisnis meminta bantuandari pihak perbankan. Akantetapi kenyataannya dalam hal ini, para pengusaha kecil tersebut tidakmemilikiakses yang signifikan ke lembaga perbankan sebagai lembaga permodalan,karena dalam hal ini lembaga-lembaga perbankan belum menjangkau

Kecil, (Malang: UIN Press, 2003), hlm.39 
kebutuhanpara pengusaha kecil, terutama di daerah dan pedesaan.

Kehadiran BMT ini diharapkan mampu menaggulangi masalah permodalan yang dialami oleh pengusaha kecil mikro, sehingga distribusi modal dan pendapatan dapat dirasakan masyarakat kecil yang tidak tersentuh oleh kebijakan pemerintah.Peluang pengembanagn BMT di Indonesia sesungguhnya sangat besar mengingat usaha mikro gan den skala pinjaman dibawah Rp 5 juta adalah segmen pasar yang dapat dilayani dengan efektif oleh lembaga ini. 2 Dengan keterbatasan kemampuanfinancial lembaga Negara dan swastatersebut maka perbankan nasional memegang peranan penting dan strategis. Dalampengembangan sektor-sektor produktif, keberadaan lembagakeuangan yang menawarkan berbagai bentuk fasilitas pembiayaan merupakan sesuatu yang penting guna mendukung kegiatan perekonomian terutama melalui pergerakan sumber-sumber pembiayaan dan penyalurannya secara efektif dan efisien. ${ }^{3}$ Di Indonesia lembaga pembiayaan ini diatur dalam keputusan presiden No. 61 tahun 1988, lembaga pembiayaan adalah badanusaha yang melakukan kegiatan usaha pembiayaan $\mathrm{m}$ dala bentuk penyediaandana atau barang modal. Dan menurut ketentuan pasal 1 ayat (2) keputusan presiden tersebut diatas, lembaga pembiayaan adlah

${ }^{2}$ Euis Amalia,Keadilan Distributif Dalam Ekonomi Islam, (Jakarta : PT Raja Grafindo, 2009), hlm.17

${ }^{3}$ Muhammad, Lembaga-Lembaga Keuangan Umat Kontemporer , (Yogyakarta: UII Press, 2000), hlm.15 badan usaha yang melakukan kegiatan pembiayaan dalam bentuk penyediaan dana atau barangmodal dengan tidak menarik dana secara langsung bagi masyarakat. ${ }^{4}$

Pembiayaan adalah penyediaan uang atau tagihan berdasarkan yang persetujuan atau kesepakatan antara bank dengan pihak lan yang mewajibkanpihak yang dibiayai untuk mengembalikan uang atau tagihan tersebut setelahjangka waktu tertentu dengan imbalan atau bagi hasil. Dan secara fungsionalada dua fungsi pokok dalam kaitan dengan kegiatan perekonomian masyarakatyang terdapat di BMT, yaitu: pengumpulan dana danpenyaluran dana. Denganberbagai macam produk yang ditawarkan oleh BMT yang bertujuan agar paranasabah tertarik pada produk yang ditawarkan, ada beberapa produk yang adadi BMT yaitu: pembiayaan bai bitsamanil ajil (BBA), pembiayaan murabahah(MBA), pembiayaan musyarakah (MSA), pembiayaan mudharabah (MDA),dan pembiayaan al-qardhul hasan.Salah satu pembiayaan yang terdapat dalam BMT Al-Mu nawir ini yaituqard al-hasan yang merupakan suatu lembaga keuangan yang bearada disekitar Kecamatan Plered.

Kehadiran BMT Al-Munawir ditengah kehidupan masyarakat melalui sistemsimpan-pinjam dalam jasa keuangan yang dapat memfasilitasi para pengusahakecil dalam produktivitas usahanya.Salah satu pembiayaan yang terdapat di BMT Al-Munair ini yaitu pembiayaan qard

\footnotetext{
${ }^{4}$ Hermansyah, Bank Dan Lembaga Keuangan Lainnya Edisi Keenam, (Jakarta : PT Raja Grafind m.12
} 
al-hasan, yang diharapkan mampu meningkatkan produktivitas usaha karena dilihat dari sistemnya, pembiayaan ini berpihak pada pelaku usaha kecil dikarenakan pembiayaan ini tidak menggunakanbunga yang tetap dan tidak mengikat.

\section{TINJAUAN TEORI}

\section{A. Pembiayaan Qard Al-Hasan}

M. Syafi' I Antonio dalam bukunya "Bank Syariah dari Teori ke Praktek"menjelaskan bahwa pembiayaan merupakan salah satu tugas pokok bank yaitupemberian fasilitas dana untuk memenuhi kebutuhan pihak-pihak yang merupakan deficit unit. ${ }^{5}$ Prof.Dr.H. Veithzal Rivai dan Andria Permata Veithzal dalam buku "Islamic Financial

management" menjelaskan bahwa pembiayaan adalah penyediaan uang atau tagihan yang dapat dipersamakan dengan itu, berdasarkan persetujuan atau kesepakatan pinjam injam mem antara lembaga keuangan pihak lain yang mewajibkan pihak peminjam untuk melunasi utangnya setelah jangka waktu tertentu, dengan lan imba atau bagi hasil. Pembiayaanqardh al-Hasan adalah suatu akad pinjaman dana non komersial na dima sipeminjam mempunyai kewajiban untuk membayar pokok ana dyang dipinjamkepada lembaga keuangan yang meminjamkan tanpa imbalan atau bagi hasildalam waktu tertentu sesuai kesepakatan, dan jugadapat diartikan perjanjianantara dua belah pihak, di mana pihak pertama memberikan uang atau barangkepada

\footnotetext{
${ }^{5}$ Syafi' i Antonio, Bank Syariah dari Teori ke Praktek, (Jakarta : Gema Insani, 2001), hlm.160.
}

pihak kedua untuk dimanfaatkan dengan ketentuan bahwa uang ataubarang tersebut harus dikembalikan persis seperti yang ia terima dari pihak pertama.

a. Tujuan dan Fungsi Pembiayaan Qardh al-Hasan

1) Tujuan Pembiayaan Qard alHasan

Tujuan pembiayaan

berdasarkan prinsip syariah adalah untuk meningkatkan kesejahteraan ekonomi sesuai dengn nilai-nilai Islam. Adapun secara mikro pembiayaan diberikan dalam rangka untuk:

1. Upaya memaksimalkan laba, artinya: setiap usaha yang dibuka memiliki tujuan tertinggi, yaitu menghasilkan laba usaha. Setiap pengusaha menginginkan mampu mencapai laba maksimal dan untuk mendapatkanhasil laba yang maksimal maka mereka perlu dukungan dana yang cukup.

2. Upaya memaksimalkan resiko, artinya: usaha yang dilakukan agar mampumenghasilkan laba maksimal, maka pengusaha harus mampu meminimalkan resiko yang mungkin timbul. Resiko kekurangan modal usaha dapat diperoleh melalui tindakan pembiayaan.

3. Pendayagunaan sumber ekonomi, artinya: sumber daya ekonomi dapat dikembangkan dengan melakukanmixing antara sumber daya alam dengansumber daya manusia serta sumber daya modal. Sumber Jika daya alam dan sumber daya manusianya ada akan tetapi sumber daya modalnyatidak ada,

\footnotetext{
${ }^{6}$ Ahmad Wardi Muslich, Fiqh Muamalat, (Jakarta : Sinar Grafika Offset, 2010), hlm. 274
} 
maka dipastikan diperlukan pembiayaan. Dengan demikian, pembiayaan pada dasarnya dapat meningkatkan daya guna sumbersumber daya ekonomi.

4. Penyaluran kelebihan dana, artinya: dalam kehidupan masyarakat ini ada pihak yang memiliki kelebihan sementara ada pihak yang kekurangan. Dalam kaitannya dengan masalah dana maka mekanisme pembiayaan dapatmenjadi jembatan dalam penyeimbangan dan penyaluran kelebihan danadari pihak yang kelebihan(surplus) kepada pihak yang kekurangan(minus) dana.

2) Fungsi Pembiayaan Qardh alHasan

Keberadaan bank syariah yang menjalankan pembiayaan berdasarkanprinsip syariah bukan hanya untuk mencari keuntungan dan meramaikanbisnis perbankan di Indonesia, tetapi juga untuk menciptakan lingkungan bisnis yang aman, diantaranya :

1. Memberikan pembiayaan dengan prinsip syariah yang tidak memberatkan debitur.

2. Membantu kaum dhuafa yang tidak tersentuh oleh bank konvensional karena tidak mampu memenuhi persyaratan yang akan ditetapkan oleh bank konvensional.

3. Membantu masyarakat ekonomi lemah yang selalu dipermainkan oleh rentenir dengan membantu melalui pendanaan untuk usaha yang dilakukan.

4. Memberikan pembiayaan dengan prinsip syariah yang tidak memberatkan debitur.

5. Membantu kaum dhuafa yang tidak tersentuh oleh bank konvensional karena tidak mampu memenuhi persyaratan yang ditetapkan oleh bank konvensional.
6. Membantu masyarakat ekonomi lemah yang selalu dipermainkan oleh rentenir dengan membantu melalui pendanaan untuk usaha yang dilakukan.

\section{b. Manfaatdan aplikasi Pembiayan Qardh al-Hasan}

Pembiayaan qardh biasanya

diberikan oleh bank kepada nasabahnya sebagai fasilitas pinjaman talangan pada saat ah nasab mengalamioverdraft. Fasilitas ini dapat merupakan bagian dari satu paket pembiayaan lain, untuk memudahkan nasabah bertransaksi. Aplikasi qardh dalam perbankan yaitu :

a. Sebagai produk pelengkap kepada nasabah yang terbukti telah loyalitas dan bonafiditasnya, yang membutuhkan dana talangan segera untuk masa yangrelatif pendek. Nasabah tersebut akan mengembalikan secepatnya sejumlah uang yang dipinjamnya.

b. Sebagai fasilitas nasabah yang memerlukan danacepat sedangkan ia tidakbisa menarik dananya karena misalnya, tersimpan dalam bentuk deposito.

c. Sebagai pinjaman dana talangan haji, dimana nasabah calon haji diberikanpinjaman talangan untuk memenuhi syarat penyetoran biaya perjalanan haji. Nasabah akan melunasinya sebelum

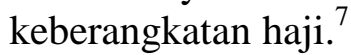

\section{B. Produktivitas Usaha Kecil}

Produktivitas secara umum diartikan sebagai hubungan antara

\footnotetext{
${ }^{7}$ Adiwarman Karim, Bank Islam Analisis Fiqh dan Keuangan, (Jakarta: PT.Raja Grafindo Persada,2004), hlm. 96
} 
keluaran (barang-barang atau jasa) dengan masukan (tenaga kerja, bahan, uang).Produktivitas adalah ukuran efesiensi produktif.Suatu perbandingan antarahasil keluaran dan masukan.Masukan sering dibatasi dengan tenaga kerja, sedangkan keluaran diukur dalam kesatuan fisik, bentuk, dan nilai.Istilah Produktivitas tidak terlepas dari:

1. Kemampuan

Tuntutan upaya peningkatan kemampuan sumber daya nusia ma sangat mutlak untukmenciptakan organisasi yang lebih baik dan mengelolanya dengan tingkat efisiensidan efektivitas yang tinggi sebagai wahana untuk mencapai berbagai tujuan yangingin dicapai.Kemampuan adalah perpaduan antara teori dan pengalaman yang diperoleh dalam praktek di lapangan, termasuk peningkatan kemampuan menerapkan teknologi yang tepat dalam rangka pening katan produktivitas kerja.

2. Kinerja

Kinerja merupakan suatu kondisi yang harus diketahui dan dikonfirmasikan kepada pihak tertentu untuk mengetahui tingkat pencapaian hasil suatuinstansi dihubungkan dengan visi yang diemban suatu organisasi atau perusahaan serta mengetahui dampak positif dan negatif dari suatu kebijakan operasional. Adapun faktor yang memengaruhi kinerja antara lain :

a. Faktor kemampuan, secara psikologis kemampuan ability pegawai terdiridari kemampuan potensi (IQ) dan kemampuan realita pendidikan Olehkarena itu pegawai perlu dtempatkan pada pekerjan yang sesuai dengan keahlian nya.

b. Faktor motivasi, motivasi terbentuk dari sikap (attitude) seorang pegawai dalam menghadapi situasi (situasion) kerja. Motivas i merupakan kondisi yang menggerakkan diri pegawai terarah untuk mencapai tujuan kerja.Sikap mental merupakan kondisi mental yang mendorong seseorang untuk berusaha mencapai potensi kerja secara maksimal.

Pada intinya ada tiga ukuran produktivitas yang harus dipertimbangkan dalam mengelola organisasi yaitu :

- Untuk tujuan strategi, apakah organisasi sudah sesuai dengan apa yang telah digariskan

- Efektivitas, sampai tingkat manakah tujuan sudah capai di dalam arti kuantitas dan kualitas

- Efesiensi, bagaimana perbandingan output di bagi ut, inp dimana pengukuran output termasuk di dalam kualitas dan kuantitas. ${ }^{8}$

\section{Pengertian Usaha kecil}

Dalam UU RI No 9 Tahun

1995 pasal 1 bahwa yang dimaksud usaha kecil adalah kegiatanekonomi rakyat yangbersakala kecil dan meemenuhi kriteria kekayaan bersih atau hasil penjualan tahunan serta kepemilikan sebagaimana diatur dalam undang-undang ini. ${ }^{9}$

Badan Pusat Statistik Indonesia (BPS) mendefinisikan bahwa usaha

\footnotetext{
${ }^{8}$ Buchari Alma, Kewirausahaan, cet VII, (Bandung : IKAPI, 2004), hlm.61-62

${ }^{9}$ Marbun,Manajemen Usaha Kecil, (Jakarta : Pustaka Binaman Pressindo, 1996), hlm.1
} 
keciladalah perusahaan yang mempekerjakan 5 sampai dengan 9 pekerja, sementaraindustri mikro atau rumah tangga mempekerjakan kurang dari 5 orang pekerjapada tiap perusahaan, termasuk pekerja yang merupakan anggota keluargdan tidak menerima upah (BPS Indonesia,1996).

Menurut Undang-Undang Republik Indonesia No 9 tahun 1995 tentang Usaha Kecil, bahwa kriteria usaha kecil adalah sebagai berikut:

- Memiliki kekayaan bersih paling banyak Rp 200.0.000, tidak termasuk tanah dan bangunan tempat usaha atau

- Memiliki hasil penjualan tahunan paling banyak $\mathrm{Rp}$ 1.000.000.000;

- Milik Warga Negara Indonesia

- Berdiri sendiri, bukan merupakan anak perusahaan atau cabang

- Berbentuk usaha orang perseorangan, badan usaha tidak yang berbadan hukum, atau badan usaha yang berbadan hukum, termasuk koperasi. ${ }^{10}$

\section{Baitul Maal wa Tamwil (BMT)}

Pengertian BMT bisa dilihat dari katabaitul maal dan baitul tamwiil, yaitu:

- $\begin{array}{lr}\text { Baitut Tamwil } \\ \text { Rumah,at-Tamwil }\end{array}$ Pengembangan Harta) melakukan kegiatan pengembangan usaha-usaha proukt if dan investasi dalam meningkatkan kualitas ekonomi pengusaha mikro dan kecil terutama dengan mendorong kegiatan menabung dan menunjang embiayaan $p$ kegiatan ekonominya.

${ }^{10}$ Marbun. ,Manajemen Usaha Kecil, hlm.115
- Baitul Maal (Bait = Rumah, Maal = Harta) menerima titipan dana Zakat, Infaq dan Shadaqah serta mengoptimalkan distribusin ya sesuai dengan peraturan dan amanahnya.

Pengertian BMT di atas menegaskan bahwa BMT mempunyai dua jenis kegiatan, yaitu baitul tamwildanbaitul maal. Baitul Tamwil mengembangkan kegiatan usaha produktif dan investasi dalam rangka meningkatkan kualitas ekonomi para pengusaha kecil menengah dengan mendorong kegiatan usahamenghimpun dana dan menyalurkannya kepada para pengusaha kecilmenengah. Sementarbaitul maalmenghimpun titipan dana zakat, infaq, dan shadaqoh, serta menjalankannya yang sesuai dengan peraturan danamanahnya. ${ }^{11}$

BMT sebagai baitullahmallyang dimiliki, dikua adalah lembaga keuangan yang kegiatan pokoknya menerima dan menyalurkan dana umatislamyang berasal darizakat, infaq dan sedeqah. Penyalurannya dialokasikan kepada mereka yang berhak (mustahiq) zakat, sesuai dengan aturan agama dan sesuai dengan manajemen keuangan modern.Sedangkan BMT sebagai baitul tamwil adalah lembaga (institusi) keuangan umat Islam yang usaha pokoknya menghimpun dana dari masyarakatdalam bentuk simpanan atau tabungan dan menyalurkan melalui pembiayaan usaha-usaha masyarakat yang produktif dan menguntungkan sesuai dengan sistem ekonomi syariah.Dengan demikian, selain menghimpun dana dari masyarakat,

\footnotetext{
${ }^{11}$ Neni Sri Imaniyati, Aspek-Aspek Hukum BMT, (Bandung, Citra Adtya Bakti, 2010),hlm. 76
} 
melalui investasi atau tabungan, kegiatan Baitul Tanwil adalah mengembangkan usaha-usaha produktif dan investasi dalam meningkatkan kualitas ekonomi umat,terutama pengusaha kecil.

BMT merupakan lembaga milik masyarakat, sehingga keberadaannya akan selalu dikontrol dan diawasi oleh masyarakt. Laba atau keuntungan yangdiperoleh BMT juga akan didistribusikan kepada masyarakat, sehingga maju mundurnya BMT sangat dipengaruhi oleh masyarakat sekitar BMT itu berada. ${ }^{12}$ Adapun ciri-ciri utama BMT adalah :

a. Berorientasi bisnis, mencari laba bersama, meningkatkan pemanfaatan ekonomi paling banyak untuk anggota dan lingkungnnya. Sebagai lembaga bisnis BMT mengembangkan usahanya pada sektor keuangan yakni simpan pinjam. Usaha ini seperti usaha perbankan yakni menghimpun dana anaggota dan calon anggota (nasabah) serta menyalurkannya kepada sektor ekonomi yang halal dan meguntungkan.

b. Bukan lembaga sosial tetapi dapat dimanfaatkan untuk mengefektifkan penggunaan zakat, infak dan sedekah bagi kesejahter aan orang banyak.

c. Ditumbuhkan dari bawah berlandaskan peran serta masyarkat disekitarnya.

d. Milik bersama masyarakat kecil bawah dan kecil dari lingkungan BMT itu sendiri,

12 H.A.Djazuli,Yadi Janwari,

Lembaga-Lembaga Perekonomian Umat Sebuah Pengenalan, (Jakarta : PT. Raja Grafindo Persada, 2002), hlm 84. bukan milik orang seorang atau orangl u r dari masyarakat itu sendiri.

\section{KERANGKA BERFIKIR}

Keterpurukan yang melanda beberapa negara berkembang, khususnya negara Indonesia masih terasa terhadap perekonomian, khususnya pengusaha kecil yang berada di pedesaan ataupun daerah-daerah yang sulit tersentuh oleh adanya lembaga keuangan, selain itu juga terdapatnya penurunan pendapatan dan banyak usaha-usaha kecil yang mengalami masalah pada usahanya sehingga berdampak pada kehidupan usaha kecil tersebut. BMT adalah lembaga ekonomi masyarakat yang bertujuan untuk mendukung kegiatan usaha ekonomi rakyat kecil, dan dijalankan berdasarkan syariat Islam.BMT berintikan dua kegiatan usaha yang mencakup baitul mal dan baitul tanwil. Tugas pokok dari BMT yakni menghimpun dana dari masyarakat dalam bentuk simpanan atau tabungan dan menyalurkannya melalui pembiayaan usaha-usaha masyarkat yang produktif dan menguntungkan sesuai dengan sistem ekonomi syariah.

Dari permasalahan tersebut, BMT memberikan suatu solusi dalam memecahkan masalah untuk membiayai usaha produktif di semua sektor ekonomi dan juga jumlah pembiayaan menurut kebutuhan usaha. Tujuan diberikannya pembiayaan adalah untuk menyediakan fasilitas permodalan untuk meningkatkan usaha, untuk memberdayakan pengusaha kecil dan pendapatan sekaligus mengembangkan BMT yang sesuai dengan prinsip syariah.Pembiayaan berdasarkan prinsip syariah adalah 
pembiayaan yang berdasarkan persetujuan atau kesepakatan antara bank dengan pihak lain yang mewajibkan pihak yang dibiayai untuk mengembalikan uang atau tagihan tersebut setelah jangka waktu tertentu dengan imbalan atau bagi hasil.Prinsip syariah bukan hanya untuk mencari keuntungan dan meramaikan bisnis perbankan di Indonesia, tetapi juga untuk menciptakan lingkungan bisnis yang aman, di antaranya: memberikan pembiayaan dengan prinsip syariah yang menerapkan sistem bagi hasil yang tidak memberatkan debitur, membantu kaum dhuafa yang tidak tersentuh oleh bank konvensi onal karena tidak mampu memenuhi persyaratan yang ditetapkan oleh bank konvensional, membantu masyarakat ekonomi lemah yang selalu dipermainkan oleh rentenir dengan membantu melalui pendanaan untuk usaha yang dilakukan.

Salah satu bentuk Pembiayaan adalah berbentuk qardh, qardh merupakan pemberian harta kepada orang lain yang dapat ditagih atau diminta kembali tanpa mengharapkan imbalan atau dengan kata lain merupakan sebuah transaksi pinjam meminjam tanpa syarat tambahan padasaat pengembalian pinjaman.

\section{HIPOTESIS}

Hipotesis adalah sarana penelitian ilmiah yang penting dan tidak bisa ditinggalkan, karena merupakan instrument kerja dari teori. ${ }^{13}$ Hipotesis juga merupakan

13 Masri Singarimbun dan Sofian

Efendi.Metode

Penelitian

Survei, cet 2,( Jakarta: LP3ES, 1989), hlm.43 jawaban sementara yang digunakan.dalam penelitian yangsebenarnya masih harus diuji kembali. Hipotesa bisa benar dan bisa saja salah, hipotesaakan diuji oleh Penulis sehingga didapatsuatu kesimpulan apakah hipotesa tersebut diterima atau ditolak. Dalam penelitian ini diperoleh hipotesa sebagai berikut : " Terdapat pengaruh positif pembiayaan qard al-hasan terhadap , produktivitas usaha kecil nasabah".

\section{METODOLOGI PENELITIAN}

\section{a. Metode Penelitian}

Penelitian mengenai pembiayaan qard al-hasan terhadap produktivitas usaha kecil nasabah pada BMT Al-Munawir adalah penelitian kuantitatif yang bersifat deskriptif analitis, yaitumemaparkan data-data yang ditemukan dilapangan dan menganalisisnya untuk mendapatkan kesimpulan yang benar dan akurat. ${ }^{14}$

\section{b. Operasional Variabel}

Berdasarkan judul penelitian yaitu Pengaruh pembiayaan Qard Al-Hasan terhadap produktivitas usaha kecil nasabah BMT Al-Munawir Kecamatan Plered Kabupaten Cirebon, maka variabelnya adalah sebagai berikut :

1.Variabel X sebagai variabel bebas (Independen) adalah variabel yang mempengaruhi variabel lain yang tidak jelas. Variabel $\mathrm{X}$ dalam

14 Cholid Narbuk, Abu Achmadi, Metodologi Penelitian, Cet. VI, (Jakarta: PT. Bumi Aksara, 2005), hlm. 44. 
penelitian ini adalah Pembiayaan Qard al-Hasan.

2. Variabel Y sebagai variabel terikat (Dependen) adalah variabel yang dipengaruhi oleh variabel lainnya. Variabel Y dalam penelitian ini adalah produktivitas usaha kecil nasabah.

\section{c. Teknik Analisis Data}

Teknik analisis data dalam penelitian ini ini adalah analisis prosentase dan Regresi linear sederhana untuk mengetahui hubungan secara linier antara satu variable independen dengan satu variabel dependen yang digunakan untuk memprediksi atau meramalkan suatu nilai variabel dependen berdasarkan variabel independen. ${ }^{15}$

Bentuk persamaan regresi untuk regresi linier sederhana sebagai berikut :

$\mathrm{Y}=\mathrm{a}+\mathrm{bX}$

Dimana :

$\mathrm{Y}=$ Variabel dependen

$\mathrm{A}=$ harga $\mathrm{Y}$ bila $\mathrm{X}=0$ (harga konstan)

$\mathrm{b}=$ angka arah atau koefesiensi regresi, yang menunjukan angka peningkatan ataupun penurunan variabel dependen $g$ didasarkan yan pada variabel. Bila b (+) maka naik, dan bila (-) maka terjadi penurunan.

$\mathrm{X}=$ Variabel independen

\section{HASIL DAN PEMBAHASAN}

A. Gambaran Distribusi Variabel

1. Pembiayaan Qardh al-Hasan

Berdasarkan dari hasil angket yang telah disebaran kepada 100

${ }^{15}$ Duwi Priyatno, Belajar Cepat Olah Data Statistik dengan SPSS , (Yogyakarta:Andi Offset,201 2),hlm.73. responden mengenai pembiayaan qardh al-hasan yang terdiri dari 10 pertanyaan, sebanyak (45\%) responden menyatakansangat setuju, sedangkan sebanyak (49\%) responden menyatakan setuju bahwa pembiayaan qardh al-hasan yang diberikan oleh pihak BMT al-Munawir itu tanpa adanya bunga, responden menyatakan sangat setuju (58\%) bahwa Pembiayan qardh al-hasan yang diberikan BMT Al-Munawir bersifat sosial,sebanyak (51\%) responden menyatakan setuju bahwa pembiayaanqardh al-hasan yang diberikan BMT Al-Munawirdapat membantu pengusaha kecil dalam menghadapi alah mas modal dengan prospek usaha yang layak, sebanyak $(58 \%)$ responden menyatakan setuju bahwa pembiayaan qardh al-hasan tidak ada bagi hasil, menyatakansangat setuju, sebanyak (58\%) bahwa PembiayanQardh al-hasan adalah untuk modal usaha, sebanyak (53\%) responden menyatakan setuju bahwa PembiayanQardh al-hasan adalah pinjaman tanpa agunan (jaminan), sebanyak (58\%) responden menyatakan setuju pembiayaanQardh al-hasan dapat menunjang kebutuhan keluarga, sebanyak (59\%) responden menyatakan setuju bahwa Pembiayaan Qardh al-hasantidaksama dengan rentenir, sebanyak $(50 \%)$ responden menyatakan bahwa Pembiayaan Qardh al-hasanadalahpembiayaan

kebajikan, sebanyak (60\%) responden menyatakanpembiayaan qardh al-hasan di BMT Al-Munawir dapat membantu dalam meningkatkan produktivitas usaha masyarakat sekitar BMT Al-Munawir.

\section{Produktivitas Usaha Kecil}


Untuk mengetahui gambaran mengenai produktivits usaha keci 1 didapat melalui data angket yang disebarkan kepada 100 responden nasabah pembiayaan BMT Al-Munawir Kecamatan Plered Kabupaten Cirebon. Diperoleh hasil sebesar (34\%) responden menyatakan sangat setuju bahwa pembiayaanQardh al-hasan dapat mendorong usaha menjadi lancer, sebanyak (48\%) responden menyatakansetuju pembiayaan Qardh al-hasan dapat meningkatkan produksi usaha, sebanyak $(48 \%)$ responden menyatakan setuju dengan adanya pembiayaanQardh al-Hasan usaha yang dikelola mampu bersaing, sebanyak (52\%) responden menyatakan setujuadanya

pembiayaanQardh al-Hasan da pat mengurangi beban hidup keluarga, sebanyak (51\%) setujupembiayaan Qardh al-hasan dapat meningkatkan keuntungan.Dengan demikian, para nasabah mengakui bahwa prduktivitas usaha kecil nasabah di BMT Al-Munawir sudah mencapai tingkat yang diinginkan setelah adanya pembiayaan qardh al-hasan dilihat ri rekpitualasi da jawaban responden diatas.

\section{B. Hasil Analisis Data Pengaruh Qardh al-Hasan Terhadap Produktivitas Usaha Kecil}

Berdasarkan hasil perhitungan analisis regresi diperoleh persamaan

$$
\mathrm{Y}=4.832+0,896 \mathrm{X}
$$

1) Jika segala sesuatu pada variabel-variabel bebas pembiayaan (qardh alhasan) dianggap konstant maka

3) Koefesien Y (Prod Produktivitas Usaha Kecil) memberikan nilai sebesar 0,896 yang berarti bahwa semakin besar yang nilai terciptasemakin besar kemungkinan
Produktivitas usaha kecil mengalamipeningkatan setelah adanya pembiayan qardh al-hasan.

Untuk mengetahui nilai kontribusi atau koefesien determinasi variabel $\mathrm{X}$ terhadap variabel $\mathrm{Y}$ diperoleh hasil 66,5\%, Artinya variabel $\mathrm{X}$ (pembiayaan Qardh al-hasan) memb erikan kontribusi terhadap variabel Y (produktivitas Usaha Kecil) sebesar $66,5 \%$. Ini berarti pengaruh variabel $X$ terhadap naik turunnya variabel Yhanya sebesar $66,5 \%$, selebihnya $33,5 \%$ berasal faktor-faktor lain.

\section{KESIMPULAN}

BMT Al-Munawir Kecamatan .Plered Kabupaten Cirebon menggunakan pembiayaanqardh al-hasan untuk modal usahanya karena pembiayaanqardh al-hasan dapat membantu pengusaha kecil dalam menghadapi masalah modal dengan prospek usaha yang layak, pembiayanQardh al-hasan adalah pinjaman tanpa agunan (jaminan), dapat menunjang kebutuhan keluarga, tidaksama dengan rentenir, pembiayaan kebajikan, dan pembiayaan qardh al-hasan di BMT Al-Munawir dapat membantu dalam meningkatkan produktivitas usaha masyarakat sekitar BMT Al-Munawir.

Pengaruh pembiayaan qardh al-hasan terhadap produktivitas usaha kecil nasabah BMT Al-Munawir Kecamatan Plered Kabupaten Cirebon diperoleh dari hasil kontribusi variabel pembiayaan qardh al-hasan $66,5 \%$. Ini berarti, pengaruh variabel $X$ (Pembiayaan Qardh-al-Hasan) terhadap variabel Y(Produktivitas Usaha Kecil) hanya sebesar $66,5 \%$, lebihnya se

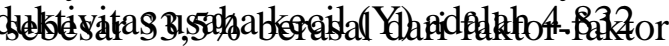
lain.

Untuk menjalankan konsep dan pelaksanaan pembiayan qardh al-hasan berdasarkan prinsip-prinsip syariah yang lebihbaik lagi, BMT perlu lebih 
memperhatikan dan meningkatkan kebijakan-kebijakan yang berkaitan dengan pembiayaan qardh al-hasankepadanasabah serta BMT ikut terhadap pengawasan dan pembinaan secara-terus menerus terhadap pengembangan usaha yang dilakukan nasabah sehingga mencapai tingkat perkembanan dan produktivitas yang di harapkan.

\section{DAFTAR PUSTAKA}

Abdad , Zaidi, 2003, Lembaga Perekonomian Ummat di Dunia Islam, Bandung : Angkasa.

Alma , Buchari, 2004, Kewirausahaan cet VII, Bandung : IKAPI.

Amalia, Niela, 2008,Peran Pembiayaan Ba'i Bitsamanil Ajil Terhadap Pmberdayaan Usaha Mikro di $B M T$, Malang: UIN Press.

Anis Ibrahim, 1972, Al-Mu 'jam Al-Wasith, Juz 2, cet II, Kairo : Dar Ihya At-Turats Al-'Arabiy.

Antonio, Syafi i, 2001 ,Bank Syariah dari Teori ke Praktek, Jakarta : Gema Insani.

A Perwataatmadja Karnaen dan Syafi'i Antonio, 1992,Apa dan Bagaimana Bank Islam ,Yogyakarta : PT.Amanah Bunda Sejahtera Solo.

Arikunto Suharsimi, 1992Prosedur Penelitian ( Sesuatu Pendekatan Praktek), Jakarta: Rineka Cipta. 1996,Prosedur Penelitian ( Sesuatu Pendekatan Praktek), Jakarta: Rineka Cipta. 2007, Manajemen

Penelitian, Cet. XI, Jakarta : Rineka Cipta.
Azis Abdul dan Mariyah Ulfah, 2010, Kapita Selekta Ekonomi Islam Kontemporer ,Bandung : Alfabeta.

Djazuli, Yadi Janwari, 2002, Lembaga-Lembaga

Perekonomian Umat Sebuah Pengenalan, Jakarta : PT. Raja Grafindo Persada.

Euis Amalia, 2009, Keadilan Distributif Dalam Ekonomi Islam, Jakarta : PT Raja $\mathrm{G}$ rafindo.

Hasan Ridwan, Ahmad, 2004, BMT dan BANK ISLAM, Bandung: Bani Quraisy.

Hermansyah, 2005,Bank Dan Lembaga Keuangan Lainnya Edisi Keenam ,Jakarta : PT Raja Grafindo Persada.

Husein, Umar, 2010Desain Penelitian MSDM dan Prilaku Karya wan (Paradigma Positivistik dan Berbasis pemecahan Masalah), , Jakarta : PT.Raja Grafindo Perada.

2003,Metode Riset Bisnis, Jakarta : PT. Gramedia Pustaka Ilmu.

Ilmi, Makhalul ，2002,Teori dan Praktek Lembaga Mikro Keuangan Syariah, Cet.1, Yogyakarta: UII Press.

Marbun, 2008, Manajemen Perusahaan Kecil, Jakarta: CV Teruna Garfica.

Muhamad, 2006,Manajemen Pembiayaan Bank Syari'ah,Yogyakarta : Penerbit Akademi Manajemen Perusahaan YKPN. 


\section{-_-_ 2000,Lembaga-Lembaga Keuangan Umat Kontemporer , Yogyakarta: UII Press.}

Rifqi, 2008, Akuntansi Keuangan Syari'ah ,Yogyakarta:P3EI Press.

Narbuko Cholid dan Abu Achmadi, 2005,Metodologi Penelitian, Cet. VI, Jakarta: PT. Bumi Aksara.

Nawawi, Hadari, 1998,Metode Penelitian Bidang Sosial, Yogyakarta: Gajah Mada University Press.

Permana Lutfiyanto, 2009, Skripsi Pen garuh Pembiayaan Musyarakah terhadap Produktivitas Usaha Kecil,STAIN.

Rid uwan, 2009, Dasar-Dasar Statistika, Bandung : Alfabeta.

2004, Metode dan Teknik Menyusun Tesis, Bandung: Alfabeta.

$\begin{array}{llr} & \text { Muhammad, } \\ & \text { 2004,Manajemen } & \text { Baitul } \\ & \text { Maal Wa } \quad \text { Tamwil, } \\ & \text { Yogyakarta: UII Press. }\end{array}$

Rivai, Veithzal dan Andria Permata Veithzal, 2008,Islamic Financial management, Jakarta, PT.Raja Grafindo Persada.

Sabiq, Sayid, 1981, Fiqh As-Sunnah, Juz 3, cet. III, Beirut : Dar Al-Fikr.

Singarimbun, Masri dan Sofian Efendi, 1989,Metode Penelitian Survei, cet 2, Jakarta: LP3ES.
Sinungan,

Muchdarsyah,

1997,Produktivitas Apa dan Bagimana, Jakarta : Bumi AksaraSoekanto,

Soerjono, 1990,Ringkasan Metodologi Penelitian Hukum Empiris ,Jakarta:Indonesia Hillco.

Soemitra, Andri, 2009, Bank \& Lembaga Keuangan Syariah, Jakarta : Kencana Prenada Media Group.

Sri Imaniyati, Neni, 201 0,Aspek-A spek Hukum BMT, Bandung : Citra Adtya Bakti.Sudarsono, Heri, 2003,Bank dan Lembaga Keuangan Lainnya : Deskripsi dan Ilustrasi, Yogyakarta : Ekonisia.

Sugiyono, 2006, Metodologi Penelitian Kuantitatif Kualitatif Dan $R \& D$, Jakarta : Alfabeta .

2007, Metode Penelitian Bisnis, Bandung: Alfabeta.

Sumodiningrat, Gunawan, 1998,Membangun Perekonomian Rakyat, Yogayakarta: Pustaka Pelajar.

Suryana, 200 1, Kewirausahaan, Jakarta: Salemba Empat.

Sutrisno Edy, 2010, Manajemen Sumber Daya Manusi, Jakarta : Kencana.

Umar, Husein, 2003, Metode Riset Bisnis, Jakarta : PT. Gramedia Pustaka Ilmu. Zuhaili,

Wahbah, 1989, Al-Figh Al-Islamiy wa Adillatuh, Juz 4, cet. III, Damaskus:Dar Al-Fikr. 
